\title{
IMPACT INVESTING AND JOB CREATION IN THE CONTEMPORARY BUSINESS ENVIRONMENT: EVIDENCE FROM THE REPUBLIC OF SERBIA
}

\author{
Nikola Stefanović1, \\ Nemanja Stanišić 1 , \\ Lidija Barjaktarović, \\ Nikola Makojević \\ 'Singidunum University, \\ Belgrade, Serbia \\ ${ }^{2}$ Faculty of Economics, \\ Kragujevac, Serbia
}

\begin{abstract}
:
This study focuses on the effects of impact investing, as a subset of socially responsible high-risk investing, on job creation. The research investigates the emerging market of the Republic of Serbia during the period 2007-2013 by tracking six companies, financed by impact investments, representing the entire population. The results indicate that during the period of rising unemployment in the country, the interventional group, consisting of the companies receiving the impact investments, created, on average, $15 \%$ of new jobs per year, while the non-interventional group, consisting of the companies not receiving the impact investments, lost, on average, $14 \%$ of existing jobs annually. To the best of our knowledge, this study is the first to focus on impact investing and job creation, and it indicates that this type of high-risk investing could be used to deal with major social challenges in the contemporary business environment, such as unemployment.
\end{abstract}

Keywords:

socially responsible investing, job creation, emerging markets.

\section{INTRODUCTION}

What is the effect of impact investing on employment in the contemporary business environment? Are new jobs created in enterprises financed by impact investors? The purpose of this study is to answer these questions by analyzing impact investments, a special form of socially responsible high-risk investments, in the emerging market of the Republic of Serbia during 2007-2013.

Over the past decade, socially responsible investing (SRI) has grown substantially (Leite \& Cortez, 2013; Reneeboog et al., 2008), and has received considerable attention from academia (Leite \& Cortez, 2015; Nofsinger \& Varma, 2014; Ballestero et al., 2012; Renneboog et al., 2008). Although SRI has been analyzed from different perspectives, its special form, impact investing, has not been explored to that extent. According to the Global Impact Investing Network (GIIN), impact investors, also known as social financers, social impact investors, blended value investors, or impact financers (Maximilian, 2013), are financiers that invest in organizations and companies with the aim to generate social and environmental benefits, along with financial returns. Unlike SRI investors, who would not sacrifice the optimal financial returns to pursue social and ethical objectives (Reneeboog et al., 2008), impact investors, by definition, would do so. While SRI investors would only avoid certain industries, perceived to be "irresponsible" (Dam \& Heijdra, 2011), such as alcohol, tobacco, arms production, and gambling, impact investors would utilize capital in order to help societies deal with their major social challenges, such as energy efficiency, healthcare, asset accumula-

Correspondence:

Nikola Stefanović

e-mail:

nstefanovic@singidunum.ac.rs tion, and job creation (Donohoe et al., 2010). Because of that, impact investing capital, as well as private capital in general, has been playing an increasing role in the areas where governments have limited financial support, such as in the case of public housing (Phibbs, 2012), clean energy sources, and unemployment. Impact investors have 
a "taste for assets" in its purest sense, as suggested by Fama and French (2007). Impact investors include philanthropic investors, angel and early stage investors, professional investors, and private sector corporate partnerships, and they utilize different forms of impact investment capital, including grants, debt capital, shareholder capital, and mezzanine/ convertible debt capital (Maximilian, 2013). Although the global impact-investing market is estimated to reach anywhere from about $\$ 500$ billion (Rangan et al., 2011) to about $\$ 1$ trillion (Maximilian, 2013) by 2020, while the intergeneration wealth transfer dedicated to venture philanthropy is estimated to reach $\$ 6$ trillion just in the U.S. (Grossman et al., 2013), the impact investing industry, as well as the effects of impact investing on employment, have not been explored in the academic literature. To the best of our knowledge, this study is the first to focus on impact investing and job creation in the contemporary business environment.

During the observed period, the Serbian economy was characterized by a high level of inflation, high trade deficit, rising public debt, and high unemployment rates (National Bank of Serbia, 2015). According to the Statistical Office of the Republic of Serbia (2016), the unemployment in the country increased from $18.10 \%$ in 2007 to $22.10 \%$ in 2013. The objective of this study is to show that impact investing could have an effect on persistent social problems, such as unemployment, even during the most difficult circumstances in the contemporary business environment, such as during the years of high unemployment. For the purpose of this research, the following hypothesis was defined: impact investing has a positive effect on employment.

\section{METHODOLOGY}

In order to conduct this study, two groups were formed, namely, an interventional group, comprising companies financed by impact investments, and a non-interventional group, consisting of companies not financed by impact investments. The interventional and non-interventional groups were tracked from 2007 to 2013 while the relevant unemployment statistics for the given period were obtained from the Statistical Office of the Republic of Serbia (2016), Labour Force Survey (LFS).

\section{Interventional Group}

For the purposes of the study, an interventional group was formed to include all active impact investments focused on job creation in the Republic of Serbia. From 2007 to 2013, six impact investments were identified, representing the entire population. The primary time-series data was collected for the six private companies from the time of investment. The following investments were identified and tracked dur- ing the period 2007-2013: a neighborhood supermarket chain, a system integrator value/value added reseller (VAR), an information technology distribution company, a parcel delivery company, a factoring company, and a high-end chocolate producer.

In order to collect the data, a survey was sent to all the companies at the beginning of each year, for the previous year, from 2007 to 2013. The companies were asked to disclose the number of their full-time employees and the number of new jobs created during the year. The base year for recording the number of employees for each company was the year of the investment by the impact investor. For the neighborhood supermarket chain and the information technology distribution company, the base year was 2007; for the system integrator value/VAR and the parcel delivery company, the base year was 2008; and for the factoring company and the high-end chocolate producer, the base year was 2010 . The data was then verified using the data from the Serbian Business Registers Agency ${ }^{1}$, as reported by the companies themselves.

\section{Non-interventional Group}

For the purpose of this study, a non-interventional group was created to resemble the interventional group. The noninterventional group included six private companies, all chosen to closely resemble the companies from the interventional group. For each company in the interventional group, a subgroup of 10 similar companies was formed. Then, for the non-interventional group, a company was chosen from each subgroup. The companies in the non-interventional group were the direct competitors (as recognized by the companies in the interventional group) in the same line of business (i.e., a neighborhood supermarket chain, a system integrator value/VAR, an information technology distribution company, a parcel delivery company, a factoring company, and a high-end chocolate producer) and of a size similar to the companies in the interventional group. Furthermore, the companies in the non-interventional group were as financially stable as the companies in the interventional group, as evidenced by the liquidity, profitability, debt, and equity ratios. Finally, none of the private companies in the noninterventional group were supported by impact investments. The data for the companies was extracted from the Serbian Business Registry. In order to reflect the interventional group, the neighborhood supermarket chain, and the information technology distribution company were added to the non-interventional group in 2007, the system integrator value/VAR and the parcel delivery company were added in 2008, while the factoring company and high-end chocolate producer were added in 2010.

1 Serbian Business Registry - retrieved from: http://www.apr.gov.rs/eng/Home.aspx. 


\section{Unemployment Statistics}

The unemployment statistics for the country were obtained from the Statistical Office of the Republic of Serbia, Labour Force Survey, for the period from 2007 to 2013. The period was characterized by the decline in economic activity (National Bank of Serbia, 2015). Table 1 shows the unemployment rate and total number of unemployed individuals in the Republic of Serbia. The descriptive statistics were then generated.

\section{RESULTS}

The results of the study indicate the following:

- Interventional and Non-interventional Groups During the observed period, the companies financed by impact investments created, on average, $15 \%$ of new jobs per year (i.e., anywhere from $7 \%$ to $28 \%$ per year). Table 2 shows the number of new jobs created in the enterprises receiving impact investments.
The results show that during the period of high unemployment, the companies not receiving impact investments lost, on average, $14 \%$ of existing jobs per year (i.e., anywhere between creating $13 \%$ to losing $65 \%$ per year). Table 3 shows the number of new jobs created and lost in the enterprises not financed by the impact investments.

- Unemployment in the country

According to the Statistical Office of the Republic of Serbia (2016), Labor Force Survey, unemployment in Serbia increased from $18.10 \%$ in 2007 to $22.10 \%$ in 2013. The average unemployment rate during the period was $19.43 \%$, while the average unemployment growth rate was $4.82 \%$. On average, each year, 11,775 individuals became unemployed, while the average growth rate of unemployed individuals was $4.91 \%$. Table 5 shows the unemployment rates, the unemployed, and their growth rates in the Republic of Serbia.

Table 1. Unemployment in the country

\begin{tabular}{lccccccc}
\hline Year & 2007 & 2008 & 2009 & 2010 & 2011 & 2012 & 2013 \\
\hline Unemployment rate & $18.10 \%$ & $13.60 \%$ & $16.10 \%$ & $19.20 \%$ & $23.00 \%$ & $23.90 \%$ & $22.10 \%$ \\
\hline Unemployed individuals & 585,472 & 445,383 & 502,982 & 568,723 & 671,143 & 701,138 & 656,120 \\
\hline
\end{tabular}

Table 2. Interventional group: new jobs created and growth rates

\begin{tabular}{lcccccccc}
\hline & 2007 & 2008 & 2009 & 2010 & 2011 & 2012 & 2013 & Average \\
\hline Total number of jobs & 390 & 635 & 757 & 844 & 907 & 1014 & 1157 & 815 \\
\hline New jobs added/lost per year & & 109 & 122 & 71 & 63 & 107 & 143 & 103 \\
\hline Cumulative number of new jobs & & 109 & 231 & 302 & 365 & 472 & 615 & 349 \\
\hline Growth rate of new jobs/year & & $28 \%$ & $19 \%$ & $9 \%$ & $7 \%$ & $12 \%$ & $14 \%$ & $15 \%$ \\
\hline
\end{tabular}

Table 3. Non-interventional group: new jobs created and growth rates

\begin{tabular}{lcccccccc}
\hline & 2007 & 2008 & 2009 & 2010 & 2011 & 2012 & 2013 & Average \\
\hline Total number of jobs & 420 & 496 & 173 & 138 & 136 & 153 & 157 & 239 \\
\hline New jobs added/lost per year & & 3 & -323 & -58 & -2 & 17 & 4 & -60 \\
\hline Cumulative number of new jobs & & 3 & -320 & -381 & -60 & 15 & 21 & -120 \\
\hline Growth rate of new jobs/year & & $1 \%$ & $-65 \%$ & $-34 \%$ & $-1 \%$ & $13 \%$ & $3 \%$ & $-14 \%$ \\
\hline
\end{tabular}

Table 4. Unemployment and growth rates

\begin{tabular}{lcccccccc}
\hline Year & 2007 & 2008 & 2009 & 2010 & 2011 & 2012 & 2013 & Average \\
\hline Unemployment rate & $18.10 \%$ & $13.60 \%$ & $16.10 \%$ & $19.20 \%$ & $23.00 \%$ & $23.90 \%$ & $22.10 \%$ & $19.43 \%$ \\
\hline Growth rate in unemployment rate & & $-24.86 \%$ & $18.38 \%$ & $19.25 \%$ & $19.79 \%$ & $3.91 \%$ & $-7.53 \%$ & $4.82 \%$ \\
\hline Unemployed individuals & 585,472 & 445,383 & 502,982 & 568,723 & 671,143 & 701,138 & 656,120 & 590,137 \\
\hline Number of newly unemployed individuals & & $-140,089$ & 57,599 & 65,741 & 102,420 & 29,995 & $-45,018$ & 11,775 \\
\hline Growth rate in unemployed individuals & $-24 \%$ & $13 \%$ & $13 \%$ & $18 \%$ & $4 \%$ & $-6 \%$ & $4.91 \%$ \\
\hline
\end{tabular}


Over the past years, certain progress has been made in developing a social impact matrix for evaluating the results of impact investing (Edward, 2013). To that end, this research indicates that impact investing, as high-risk investing, could have a positive effect on job creation in the contemporary business environment. Furthermore, it quantifies the results of impact investments and shows that during the period 2007 - 2013, the companies financed by impact investments generated, on average, $15 \%$ of new jobs per year, showing the positive effects of impact investing on employment. According to the Statistical Office of the Republic of Serbia (2016), the unemployment in Serbia increased from 18.10\% in 2007 to $22.10 \%$ in 2013 , while the average unemployment growth rate was $4.82 \%$. In addition, the companies from the noninterventional group, which did not receive impact investments, lost, on average, $14 \%$ of existing jobs per year, in line with the rising general unemployment in the country during the period 2007-2013. Although the results indicate that impact investing could be used to deal with social challenges (Donohoe et al., 2010), such as job creation, it is not readily available in the market. Because of that, and in order for the industry to grow, the government has to assume a more proactive role in building many aspects of the market for impact investments (Wood et al., 2013).

\section{CONCLUSION}

The study indicates that impact investing, as a special form of high-risk investing, has a positive effect on job creation, even during the periods of high unemployment, and it also suggests that countries could use the capital to deal with major social challenges in the contemporary business environment, such as unemployment. To the best of our knowledge, this is the first study to focus on impact investing and its effects on employment.

Further research could focus on the impact investments in broader geographic areas, such as Southeast Europe, Europe, or even larger samples. Furthermore, future studies could place special emphasis on measuring the monetary value of benefits realized by impact investing, such as employment, using the social return on investment or any alternative methodology. Finally, potential research studies could focus on other benefits realized by impact investments, such as the potential increase in youth employment, low-skilled workers' wages, health and pension benefits.

\section{REFERENCES}

Ballestero, E., Bravo, M., Perez-Gladish, B., Arenas, P., \& PlaSantamaria, D. (2012). Socially Responsible Investment:
A multi-criteria approach to portfolio selection combining ethical and financial objectives. European Journal of Operational Research, 216(2), 487-494. doi:10.1016/j. ejor.2011.07.011.

Dam, L., \& Heijdra, B. (2011). The Environmental and Macroeconomic Effects of Socially Responsible Investment. Journal of Economic Dynamics \& Control 35, 1424-1434. doi:10.1016/j.jedc.2011.05.005.

Donohoe, N., Leijonhufvud, C., \& Saltuk, Y. (2010). Impact Investments: An Emerging Asset Class, J.P. Morgan, 1-96. Retrieved from: http://www.rockefellerfoundation.org/uploads/ files/2b053b2b-8feb-46ea-adbd-f89068d59785-impact.pdf.

Edward, J. (2013). Interrogating the theory of change: evaluating impact investing where it matters most. Journal of Sustainable Finance \& Investment 3(2), 95-110. doi: 10.1080/20430795.2013.776257.

Fama, E.F., \& French, K.R. (2007). Disagreement,Tastes and Asset Prices. Journal of Financial Economics, 82(3), 667-689. doi:10.1016/j.jfineco.2006.01.003.

Grossman, A., Apleby, S., \& Reimers, C. (2013). Venture Philanthropy and Its Future. Harvard Business School Note, 1-21.

Leite, P., \& Cortez, M. (2015). Performance of European socially responsible funds during market crises: Evidence from France. International Review of Financial Analysts. doi:10.1016/j.irfa.2015.05.012.

Leite, P., \& Cortez, M. (2014). Style and performance of international socially responsible funds in Europe. Research in International Business and Finance 30, 248-267. doi:10.1016/j. ribaf.2013.09.007.

Maximilian, M. (2013). Status of the Social Impact Investing Market: A Primer. Impact Economy Working Papers, 4(1), 1-13. Retrieved from: http://www.impacteconomy.com/papers/ ie_primer_june2013_en.

National Bank of Serbia (2015). Macroeconomic Developments in Serbia. 1-20. Retrieved from: http://www.nbs.rs/export/ sites/default/internet/english/18/18_3/presentation_invest. pdf.

Nofsinger, J., \& Varma, A. (2014). Socially responsible funds and market crises. Journal of Banking and Finance 48, 180-193. doi:10.1016/j.jbankfin.2013.12.016.

Phibbs, P. (2012). Social Housing: Measures to Attract Private Finance. International Encyclopedia of Housing and Home, 460-463. doi:10.1016/B978-0-08-047163-1.00248.

Rangan, K., Appleby, S., \& Moon, L. (2011). The Promise of Impact Investing. Harvard Business School Note, 1-21.

Renneboog, L., Horst, J., \& Zhang, C. (2008). The price of ethics and stakeholder governance: The performance of socially responsible mutual funds. Journal of Corporate Finance, 14(3), 302-322. doi:10.1016/j.jcorpfin.2008.03.009.

Renneboog, L., Horst, J., \& Zhang, C. (2008). Socially responsible investments: Institutional aspects, performance, and investor behavior. Journal of Banking \& Finance 32, 1723-1742. doi:10.1016/j.jbankfin.2007.12.039.

Statistical Office of the Republic of Serbia (2016). Labour Force Survey. Retrieved from: http://webrzs.stat.gov.rs/WebSite/ repository/documents/00/01/35/43/SB-578_ARS_2013SAJT.pdf.

Wood, D., Thornley, B., \& Grace, K. (2013). Institutional impact investing: practice and policy. Journal of Sustainable Finance \& Investment, 3(2), 75-94. doi:10.1080/20430795.2 013.776256. 


\section{INVESTIRANJE SA POZITIVNIM REPERKUSIJAMA NA ŠIRU ZAJEDNICU I OTVARANJE} NOVIH RADNIH MESTA U SAVREMENOM POSLOVNOM OKRUŽENJU U SRBIJI

\section{Apstrakt:}

U radu se ispituje uticaj ulaganja sa pozitivnim reperkusijama na širu zajednicu, kao podgrupe društveno odgovornog ulaganja visokog rizika, na otvaranje novih radnih mesta. Istraživanjem je obuhvaćeno tržište u razvoju Republike Srbije u periodu od 2007. do 2013. godine na primeru šest preduzeća koja se oslanjaju na ulaganja sa pozitivnim reperkusijama na širu zajednicu. Rezultati pokazuju da je tokom perioda povećane nezaposlenosti u zemlji, osnovna grupa, koja obuhvata preduzeća koja dobijaju investicije sa pozitivnim reperkusijama na širu zajednicu, zabeležila u proseku $15 \%$ novih radnih mesta godišnje, dok je uporediva grupa, koju čine preduzeća koja ne dobijaju investicije sa pozitivnim reperkusijama na širu zajednicu, gubila u proseku $14 \%$ postojećih radnih mesta na godišnjem nivou. Koliko nam je poznato, ova studija je prva koja se prevashodno bavi uticajem investicija sa pozitivnim reperkusijama na širu zajednicu i otvaranjem novih radnih mesta, što potvrđuje da bi ovakav vid visokorizičnih ulaganja mogao da se koristi za rešavanje ozbiljnih društvenih izazova u savremenom poslovnom okruženju, poput nezaposlenosti.

\section{Ključne reči:}

društveno odgovorno ulaganje, otvaranje novih radnih mesta, tržišta u razvoju. 